\title{
The Impact of the English Language used in Social Media on English Language Learners at the Undergraduate Level in Sargodha
}

\author{
Rana Muhammad Basharat Saeed \\ ${ }^{1}$ M. Phil Scholar, The University of Lahore, Sargodha Campus, Pakistan \\ engr.basharatrana@gmail.com
}

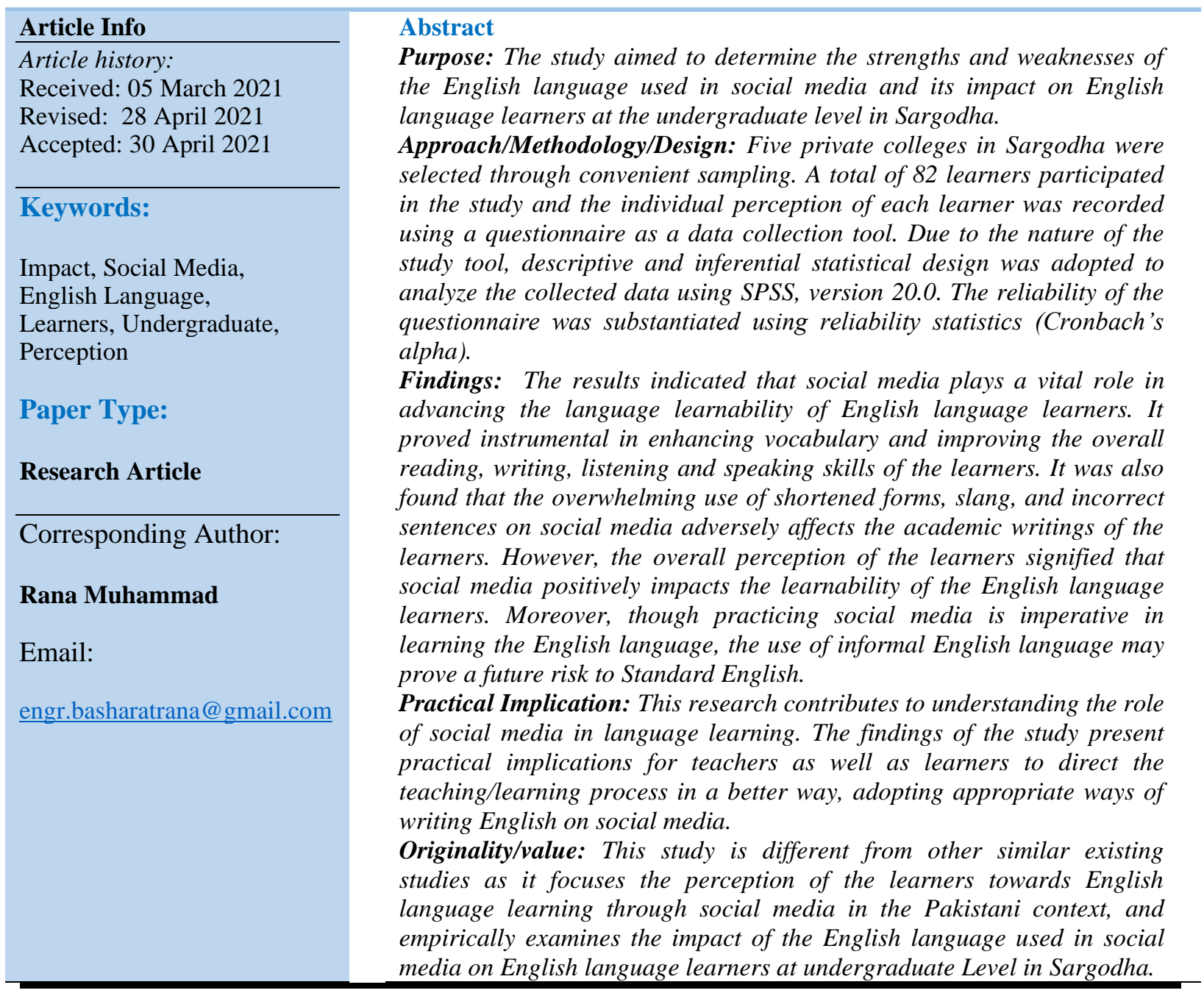

\section{Introduction}

The world has dramatically been changed as a consequence of enchanting technological advances in the sphere. The ways of living and approaches to communicate with one another have entirely been altered through the adaption of high-tech contraptions. Technology impelled the evolution of mass media in the early $20^{\text {th }}$ century and mass media revolutionized human communication as a result. The power of mass media has globally 
been acknowledged as it has immensely influenced and galvanized communication on the planet (Coyle \& Vaughn, 2008). Derakhshan \& Hasanabbasi (2015) mention that social networking services (SNS), as a result of digital media, have grown popular with the use of modern tools around the world that have been capacitated to interact with a greater number of people on a global scale. In a fast-paced world society, social networks expedite convenient and fast interactions.

Although teenagers write frequently on social media, but the quality of writing is not satisfactory due to the informal use of English. Students also use social media to get quick feedback and assistance to learn English (Jaffar, Nurunnabi, \& Bano, 2021). English as a dominant language used in social media brings both positive and negative effects on learning of the students while using informal language in their conversations. The use of inappropriate grammar, misspellings, and speech used informally in wrong contexts negatively impact the learning of the learners. On the positive end, social media gives awareness of the language mistakes as some readers pinpoint the grammatical errors in their comments (Namaziandost \& Nasri, 2019; Ochonogor, A. N. O., \& Achugbue, 2012). The increasing demands of fast and easy communication have elevated the disposition to use English abbreviations and informal language with grammatical errors. The overwhelming use of slang on social media has misled internet users to incorrect grammar and spellings. Because of the growing popularity of slang, some of them have also become part of regular English communication (Ochonogor \& Achugbue, 2012). Consequently, there is a tendency of general languishing in proper language learning because mostly the conversations are crowded with misspellings and abbreviations (Izmaylova, Zamaletdinova, \& Zholshayeva, 2017).

J et al. (2019) state that social media communication is most commonly concerned with pragmatics and reciprocal comprehensibility, and the use of inappropriate language and abbreviations may be comprehensible among young but older people frequently encounter issues in comprehending the informal and modern language. Namvar (2014) clarifies that the usage of informal language on social media has made the language simpler for many people; however, the potential to connect deep thoughts and feelings is reasonably crumbled.

Winarto (2019) explores that on social media, targeting to save typing time and character space, correct spellings, and grammar are generally abandoned in favour of popular acronyms and slangs which have been deep-seated in the minds of the social media community at large. The ever-evolving nature of English keeps it in a perpetual state of regeneration and alteration. When we observe the English language on social media, we come across several acronyms or lingo usually in conversations, captions, and comments. Hashmi (2019) suggests that although the familiarity and usage of acronyms, abbreviations, and slang is instrumental in handling reckless and swift conversations on social media, it does not compulsorily mean that the whole conversation is populated and jammed with their excessive use. Social media users must know about the right usage of acronyms, abbreviations, and slang at the right time while communicating with a large audience. They should use those acronyms, abbreviations, or slang that are popular and well understood by the audience on social media. The overwhelming use of textspeaks and slangs is deemed inappropriate during online conversations on social media. Despite all, social media has impacted both acceptably and 
undesirably the ways people write and convey their thoughts to others in English (Izmaylova et al., 2017; Ochonogor \& Achugbue, 2012).

Osharive (2015) highlight that social media can affect the English learning skills of the students either positively or negatively; however, it all depends on their cognition that how did they learn English in their classrooms with correct grammar and spellings and how they are employing it on social media using incorrect grammar, misspellings, abbreviations and slangs. This will help students to know about the negative aspects of unofficial and colloquial English used in social media that may deteriorate their formal English used in their academics. If students are unable to move from informal writing to formal writing, it will worsen their academic writing (Rao, 2019a).

In considering the strengths of the language used in social media, a number of assumptions can be sheathed to analyze the perception of the English language learners in learning the English language. Communication with people belonging to different countries and cultures, especially with native speakers advances the English language to an extended level. Substantial amount of exposure and extensive use of the English language on social media boosts the interest of the English language learners in learning the English language (Gibreel, 2018). Online games provide an opportunity to English language learners to share information with others using the English language. Sharing of content, stimulating debates, answering queries, and encouraging online discussions in English by educators on social media are helpful in learning the English language (Rudis \& Postic, 2018).

The perception of the English language learners while focusing on the weaknesses of language used in social networks is highlighted in a number of studies such as the works done by Thurairaj, Hoon, Roy, \& Fong (2015), Raut \& Patil (2016), Siddiqui \& Singh (2016), etc. The introduction of crude language in the form of abbreviations, short forms and slang adversely impacts English language learning. The use of wrong grammar in writing English sentences affects the writing skills of English language learners. Absence of the real language interactions on social media also lessens the effective learning of the English language (Haque, 2017).

Since, English is a dominant language on social media, therefore social interactions are stimuli for the English language learners in Pakistan to converse with the native English speakers and the English speakers belonging to diverse cultures (Raza, 2015). The present study is focused on the strengths and weaknesses of the English language used in social media considering its positive and negative impacts on the English language learners at the undergraduate level in Sargodha. It investigates the extent to which the English language used in social media is affecting the learnability of the English language learners at the undergraduate level in Sargodha.

\section{Null Hypotheses}

In order to achieve the above mentioned objectives, the following hypotheses were developed: 
$\mathrm{H}_{0} 1$ : The language used in social media does not positively impact the perception and the language learnability of the English language learners at the undergraduate level. $\mathrm{H}_{0} 2$ : The language used in social media does not negatively impact the perception and the language learnability of the English language learners at the undergraduate level.

\section{Literature Review}

Technological advancements speak for theoretical outlines and practical insights towards the enhancement of skills, attitudes and knowledge among students and teachers (Starkey, 2011). Social media is an umbrella term that includes internet-based websites to promote social interactions among individuals fulfilling the purpose of interpersonal communications around the globe (Brown, 2015). The term social media was primitively introduced in 1994 when the earliest web-based social networking site Geocities was rooted. Later, Sixdegrees.com and AOL (America Online) instant messenger were launched in 1997. Social networking sites really gained popularity when Friendster was launched in 2002, and sooner a year afterwards MySpace and LinkedIn were simultaneously launched. Subsequently, Facebook, the most sought-after site, was introduced in 2004 which was subsequently followed by Twitter in 2006 as another popular social media innovation (Abbasova, 2016a; Dickey \& Lewis, 2010).

Prensky in 2001 introduced the terms 'digital natives' and 'digital immigrants'. The 'digital natives' are the people born with technologies around them and the 'digital immigrants' are those people born in the $19^{\text {th }}$ and $20^{\text {th }}$ centuries to harmonize themselves with the emerging technologies (Walker \& Zur, 2011). According to Bureau (2012), there are approximately $27 \%$ of people under 15 years of age surrounded by the latest technology since they were born. The 'digital natives' might perceive a foreign language more quickly and in a better way while playing online games and interacting with online friends. The majority of the people in the society are 'digital immigrants' and they need to espouse emerging technologies to commix with 'digital natives'. There is a huge gap in educational understanding between new and older generations, particularly English education among other disciplines that seems to be more learnable and teachable from various perspectives (Suša Vugec, 2014). Oliver (2002) describes that Information and Communication Technology (ICT) has become a part of our everyday life. Nonetheless people need to alter their skills to comply with more intricate and innovative tasks. Likewise the digital literacies have necessarily become a part of education by the turn of the $21^{\text {st }}$ century.

Van Den Beemt et al. (2020) believe in the "unstoppable power of social media". Social media is imperative in disseminating knowledge across the world to bring out the advantages if appropriately harnessed. Social media particularly Facebook provides learners the real-time learning opportunities regarding linguistic and cultural interchange (Latip-Yusoph, 2016). Twitter not only improved students' engagement but also enhanced students' interactions with peers and instructors on deeper interpersonal levels (Maclean et al., 2013). Facebook proved instrumental in improving learners' vocabulary, grammar, writing skills and acquiring new knowledge. It also offered a platform for the learners just like an online information center (Slavin \& Cheung, 2005; Wil et al., 2019). 
There are some advantages associated with the use of social media and facilitation of the English language learning is one of them which results in English proficiency (Abbas et al., 2019; Hwang, 2005). According to Ansari \& Khan (2020), social media are satiated with interactions and interactions are quite instrumental in the process of language learning. They emphasized the concern of social media in the language learning process considering social media as an electronic device that is latest in the process of second language learning. In fostering language learning, social media plays an indispensible role in providing a vast pattern of authentic materials. According to Rudis \& Postic (2018), there are a number of games that enhance vocabulary and improve the interest of the English language learners towards the language learning process in a flexible and tranquilized atmosphere. Children can unravel real-world troubles by arranging their queries, planning and organizing their learning and research, and implementing strategies. Abraham \& Saini (2015) argue that the language learners improve their life skills by the use of various social media which facilitate them to advance their positive trends towards the English language.

Le (2018) suggests that students can be encouraged to use social media with limited time for real English communications to enhance their communication skills. Faizi and El Fkihi (2018) claim that the use of Facebook enhanced communication among students and improved their language skills. AlSaleem (2018) believes that students improved their sociopragmatic skills and competence by the use of Facebook . Similarly, Alfaki (2018) states that social media was found effective in the development of language production considering production as an integral element of language learning. Bakeer (2018) think that appropriation of vocabulary is one of the most cogent effects of social media on written and verbal English. According to George (2018), social networks proved to be a useful platform in advancing different language skills such as reading, writing and vocabulary enhancement. In reading, users avail themselves opportunities of reading a variety of comments, messages, and in writing, they get the experience of composing different messages incorporating new English words.

Nevertheless, some educators and researchers refute the role of social media in language learning. Al-Rahmi \& Othman (2013) argue that some students take social media as a helpful tool; however, they also pinpoint some hurdles keeping in view the weaknesses of internet usage at home. Tariq, Mehboob, Khan, Ullah (2012a) express that although social networks can be used for learning purposes but these are frequently used for time killing and purposeless activities which adversely affect students' academics. Davis III, Deil-Amen, Rios-Aguilar, \& Gonzalez Canche (2012) lament that education is extremely essential in an individual's life but unfortunately social media is not used for the sake of education despite the immense interest of the teenagers in social networks. Brown (2015) asserts that some students believe that social media has created a diversion and its use is time-consuming.

Owusu-Acheaw \& Larson (2015) proposed a study carried out to examine the usage of social networks by the students. The study revealed that students used social platforms frequently for their leisurely activities such as watching videos and films, and discussing political and religious issues. According to Okumura (2016), mostly the interactions on Facebook are not of educational concern and social media are not always practiced for a positive cause. 
Students usually use social media to deal with customary subjects. Abbasova (2016a) argues that the negative effects of social media on students' academic performance are far more than its positive outcomes.

Many linguists who believe that the English language used on the internet will seriously affect Standard English. According to Winarto (2019), SMS (Short Messages Service) is considered the basis of slang used on social media. These code words lack proper grammatical structures. For instance, the repeated use of a letter in a word as in 'oooops', repeated use of punctuation marks as in 'hello!!!!!' and use of capital letters in words for the sake of emphasis. Mukhtar, Tatlah, \& Saeed (2011) argue that electronic communication has affected students writing inimically resulting in serious spelling and grammatical errors. It has led the students to incorporate informal language in their assignments. He further adds the use of informal language is also frequently found in research papers at the university level. According to Singh \& Sachan (2017), in the present age of technology, the excessive and unusual use of the English language without proper spellings proved to be a hurdle in writing Standard English on social media. Therefore, there exists a huge potential that digital natives may take Standard English for granted in the future.

According to the National School Board Association (NSBA), nearly $60 \%$ of the students in Pakistan discuss about their academic issues on social networks (Kauser \& Awan, 2019). Considering the above-mentioned related literature, the present work aims at analyzing the impact of the English language used in social media on English language learners at the undergraduate level in Sargodha.

\section{Methodology and Procedures}

\section{Research Design}

Since, the study is quantitative, the descriptive and inferential statistical design was adopted to analyze the collected data and to achieve the objective of the study.

\section{Population}

The population of the current study comprised five private colleges located in Sargodha named Army Public School \& College (APS\&C), Dar-e-Arqam College, The Reader College, ILM College, and Superior College.

\section{Sample and Sampling Technique}

In the present work, $50 \%$ of the total population was taken as the sample of the study. A convenient sampling technique, a type of non-probability sampling, was employed to draw the sample from the population. There were only 82 participants who responded during the pandemic situation due to COVID-19.

\section{Research Instrument}

A Likert scale questionnaire was developed as data collection tool with twenty closely related items. The questionnaire contained closed-ended items to obtain factual information from the 
English language learners at the undergraduate level (Delport, 2005; Roopa \& Menta Satya, 2012).

\section{Data Collection}

The questionnaire was developed as an online Google form on Google Drive to get online responses of the English language learners. Physical data collection was virtually impossible because all the educational institutions were closed by the government of Pakistan due to the outbreak of COVID-19. Hence, an online questionnaire was developed for the sake of data collection. The online link of the questionnaire was further shared to nearly 350 students on their WhatsApp numbers as well as through emails, to fill out the form and subsequently submit it in response. Total 82 students as English language learners responded, out of which 24, 31 and 27 learners were from Army Public School \& College (APS\&C), ILM College, and Superior College respectively.

\section{Data Analysis}

After collecting the online responses from the learners, the data were analyzed using SPSS (Statistical Package for Social Sciences), version 20. Descriptive statistics were applied to summarize and analyze the empirical data, and inferential statistics were used to examine the relationship between the variables to determine the impact of the language used in social media on English language learners (Greasley, 2007). The results were presented in tabular form.

\section{Reliability Statistics}

In statistics, reliability is a gauge of consistency in results, and higher consistency in results indicates higher reliability, and vice versa (Edwin, 2019).

\section{Table 3-1 Reliability Statistics}

\begin{tabular}{cc}
\hline Cronbach's Alpha & N of Items \\
\hline .939 & 20 \\
\hline
\end{tabular}

Table 2-1 exhibits the outcomes of reliability statistics for 20 items. The value obtained for Cronbach's Alpha through reliability statistics was 0.939 which is greater than 0.7 . This indicates that the internal consistency of the data collected is excellent.

\section{Delimitations of the Study}

The whole research with all its operational requirements was carried out in Sargodha, an educational division located in the province of Punjab, Pakistan. Therefore, the results obtained may not be appurtenant in other geographical regions inside or outside the country, but may-be generalized for the related future researches.

\section{Results and Discussion}

\section{Demographics}

The following three tables; Table 4-1, Table 4-2, and Table 4-3 contain demographic data about the learners' institutions, educational qualification, and age group. 
Table 4-1 Institutions

\begin{tabular}{|c|c|c|c|c|c|}
\hline & & Frequency & Percent & Valid Percent & $\begin{array}{c}\text { Cumulative } \\
\text { Percent }\end{array}$ \\
\hline \multirow{4}{*}{ Valid } & APS\&C Sargodha & 24 & 28.9 & 29.3 & 29.3 \\
\hline & ILM College Sargodha & 31 & 37.3 & 37.8 & 67.1 \\
\hline & Superior College Sargodha & 27 & 32.5 & 32.9 & 100.0 \\
\hline & Total & 82 & 98.8 & 100.0 & \\
\hline Missing & System & 1 & 1.2 & & \\
\hline Total & & 83 & 100.0 & & \\
\hline
\end{tabular}

The data given in Table 4-1 describes the research participants from three private institutions in Sargodha named APS\&C, ILM College, and Superior College. Total 82 learners responded out of the sample of 193 students. There were 24(29.3\%), 31 (37.8\%), and 27 (32.9\%) learners from APS\&C, ILM College, and Superior College respectively. It shows that the learners who participated from ILM College were maximum in number while the learners from APS\&C were minimum in number.

Table 4-2 Educational Qualification

\begin{tabular}{|c|c|c|c|c|c|}
\hline & & Frequency & Percent & Valid Percent & Cumulative Percent \\
\hline \multirow{3}{*}{ Valid } & Intermediate $(\mathrm{FSc})$ & 24 & 28.9 & 29.3 & 29.3 \\
\hline & BS English (Hons.) & 58 & 69.9 & 70.7 & 100.0 \\
\hline & Total & 82 & 98.8 & 100.0 & \\
\hline Missing & System & 1 & 1.2 & & \\
\hline Total & & 83 & 100.0 & & \\
\hline
\end{tabular}

In Table 4-2, the educational qualification of the undergraduate learners has been described. Among the total 82 learners, there were 24 (29.3\%) intermediate students and 58 (70.07\%) BS English (Hons.) students who responded as learners. It is clear from the table that the number of learners studying in BS English (Hons.) is greater than the number of learners studying in intermediate (FSc).

Table 4-3 Age Group

\begin{tabular}{lccccc}
\hline & & Frequency & Percent & Valid Percent & Cumulative Percent \\
\hline \multirow{3}{*}{ Valid } & $16-18$ & 24 & 28.9 & 29.3 & 29.3 \\
& $18-20$ & 38 & 45.8 & 46.3 & 75.6 \\
& $20-22$ & 20 & 24.1 & 24.4 & 100.0 \\
\multirow{2}{*}{ Missing } & Total & 82 & 98.8 & 100.0 & \\
Total & System & 1 & 1.2 & \\
\hline
\end{tabular}

The table 4-3 covers the age group of the learners at the undergraduate level. There were 24 (29.3\%) learners aged between 16 and 18, and most of them were intermediate students. There were $38(46.3 \%)$ learners aged between 18 and 20, and the majority of them were BS 
English (Hons.) students. Similarly, there were 20 (24.4\%) students aged from 20 to 22 who were BS English (Hons.) students. Hence, it is clear from the above data that the number of learners aged 18-20 was the highest while the learners aged 16-18 were greater in number compared to the learners aged 20-22.

\section{Descriptive Analysis}

In the descriptive analysis, the data is presented in tabular form for the interpretations of the results.

Table 4-4 Students at the undergraduate level frequently use different social media tools.

\begin{tabular}{llcccc}
\hline & & Frequency & Percent & Valid Percent & Cumulative Percent \\
\hline \multirow{4}{*}{ Valid } & Strongly Agree & 49 & 59.0 & 59.8 & 59.8 \\
& Agree & 30 & 36.1 & 36.6 & 96.3 \\
& Neutral & 3 & 3.6 & 3.7 & 100.0 \\
\multirow{2}{*}{ Missing } & Total & System & 1 & 98.8 & 100.0 \\
Total & & 83 & 1.2 & \\
\hline
\end{tabular}

Table 4-4 illustrates the responses about the usage of social media tools by the respondents at the undergraduate level. Total 82 students responded, out of which 49 (59.8\%) learners 'strongly agreed' and 30 (36.6\%) learners 'agreed' with the statement that the students at the undergraduate level are frequent users of social media tools. Only $3(3.7 \%)$ of the learners remained uncertain about the statement. It indicates that the learners who 'strongly agreed' with the statement were by far the highest. The learners who 'agreed' with the statement were also in considerable number while the learners who remained 'neutral' were scant in number. The overall responses show that the majority of the students use different social media tools at the undergraduate level.

Table 4-5 Students at the undergraduate level prefer the English language while communicating with their friends and classmates on social media.

\begin{tabular}{|c|c|c|c|c|c|}
\hline & & Frequency & Percent & Valid Percent & Cumulative Percent \\
\hline \multirow{5}{*}{ Valid } & Strongly Agree & 14 & 16.9 & 17.1 & 17.1 \\
\hline & Agree & 44 & 53.0 & 53.7 & 70.7 \\
\hline & Neutral & 19 & 22.9 & 23.2 & 93.9 \\
\hline & Disagree & 5 & 6.0 & 6.1 & 100.0 \\
\hline & Total & 82 & 98.8 & 100.0 & \\
\hline Missing & System & 1 & 1.2 & & \\
\hline Total & & 83 & 100.0 & & \\
\hline
\end{tabular}

The results given in Table 4-5 convey information about the language preference of the learners at the undergraduate level on social media. Among 82 learners, 14 (17.1\%) learners 'strongly agreed' and 44 (53.7\%) learners 'agreed' that they prefer the English language while conversing with their friends and classmates on social media. There were only $5(6.1 \%)$ 
learners who 'disagreed' with the statement and the rest of the learners remained undecided. This points out that an ample number of the learners 'agreed' and a skimpy number of the learners 'disagreed' with the statement. Even the learners who 'strongly agreed' were lesser in number as compared to the learners who 'strongly agreed'. That's why, the overall trend of the responses shows that the use of the English language on social media is preferred by the majority of the students at the undergraduate level.

Table 4-6 Today, social media is an easy source to learn the English language.

\begin{tabular}{|c|c|c|c|c|c|}
\hline & & Frequency & Percent & Valid Percent & Cumulative Percent \\
\hline \multirow{5}{*}{ Valid } & Strongly Agree & 38 & 45.8 & 46.3 & 46.3 \\
\hline & Agree & 38 & 45.8 & 46.3 & 92.7 \\
\hline & Neutral & 5 & 6.0 & 6.1 & 98.8 \\
\hline & Disagree & 1 & 1.2 & 1.2 & 100.0 \\
\hline & Total & 82 & 98.8 & 100.0 & \\
\hline Missing & System & 1 & 1.2 & & \\
\hline Total & & 83 & 100.0 & & \\
\hline
\end{tabular}

The data in table 4-6 presents the responses of the learners regarding social media considered as an easy source of English language learning. There were 38 (46.3\%) learners who 'strongly agreed' and an equal number of learners who 'agreed'. Only 1 (1.2\%) learner 'disagreed' with the statement and 5 learners stayed 'neutral'. These results noticeably indicate that the learners who 'strongly agreed' and 'agreed' with the statement are much greater in number as compared to the negligible number of the learners who 'disagreed' or remained 'neutral'. It shows that most undergraduate students consider social media a convenient source of learning the English language.

Table 4-7 Social media encourages you to employ and learn a variety of new English words which improves your vocabulary.

\begin{tabular}{llcccc}
\hline & & Frequency & Percent & Valid Percent & Cumulative Percent \\
\hline \multirow{4}{*}{ Valid } & Strongly Agree & 37 & 44.6 & 45.1 & 45.1 \\
& Agree & 40 & 48.2 & 48.8 & 93.9 \\
& Neutral & 3 & 3.6 & 3.7 & 97.6 \\
& Disagree & 2 & 2.4 & 2.4 & 100.0 \\
\multirow{2}{*}{ Missing } & Total & System & 82 & 98.8 & 100.0 \\
Total & & 1 & 1.2 & & \\
\hline
\end{tabular}

The data in Table 4-7 elucidates the responses of the learners for the statement that the English language used in social media assists the English language learners to improve their vocabulary. Among the total respondents, 37 (45.1\%) respondents 'strongly agreed' and 40 (48.8\%) learners 'agreed' with the statement. Only $2(2.4 \%)$ learners 'disagreed' and 3 (3.7\%) learners stayed 'neutral' about the statement. It shows that the respondents who 'agreed' with the statement were the highest in number and the respondents who 'disagreed' were the lowest in number. A substantial number of the learners 'strongly agreed' with the 
statement, however, an insignificant number of the learners also stayed 'neutral'. Hence, the majority of the English language learners at the undergraduate level reflect that social media encourages them to incorporate and learn a variety of new English words during the online conversation which ultimately enhances vocabulary.

Table 4-8 Social media encourages you to read, understand, and respond promptly which improves your readability and comprehension skills.

\begin{tabular}{llcccc}
\hline & & Frequency & Percent & Valid Percent & Cumulative Percent \\
\hline \multirow{4}{*}{ Valid } & Strongly Agree & 39 & 47.0 & 47.6 & 47.6 \\
& Agree & 35 & 42.2 & 42.7 & 90.2 \\
& Neutral & 8 & 9.6 & 9.8 & 100.0 \\
\multirow{2}{*}{ Missing } & Total & 82 & 98.8 & 100.0 & \\
Total & System & 1 & 1.2 & & \\
\hline
\end{tabular}

Table 4-8 encompasses the responses regarding the improvement in reading and comprehension skills of the respondents through social media. There were $39(47.6 \%)$ and 35 (42.7\%) respondents who 'strongly agreed' and 'agreed' respectively, and only $8(9.8 \%)$ respondents remained undecided. So, it can easily be figured out from the results that there were a large number of the learners who 'strongly agreed' and 'agreed' with the statement, but no one 'disagreed'. There were only a scant number of the learners who kept themselves in the middle of the road. It shows that social media is instrumental in improving the readability and comprehension skills of the learners at the undergraduate level.

Table 4-9 Audio conversations through social media tools in English help you in improving your listening and speaking skills.

\begin{tabular}{llcccc}
\hline & & Frequency & Percent & Valid Percent & Cumulative Percent \\
\hline \multirow{4}{*}{ Valid } & Strongly Agree & 39 & 47.0 & 47.6 & 47.6 \\
& Agree & 40 & 48.2 & 48.8 & 96.3 \\
& Neutral & 3 & 3.6 & 3.7 & 100.0 \\
\multirow{2}{*}{ Missing } & Total & 82 & 98.8 & 100.0 & \\
Total & System & 1 & 1.2 & \\
\hline
\end{tabular}

Table 4-9 illustrates the results regarding the perception of the learners about the improvement in their listening and speaking skills through audio conversations on social media. The number of the learners who 'strongly agreed' with the statement was $39(47.6 \%)$ and the number of respondents who 'agreed' was 40 (48.8\%). Only 3 (3.7\%) respondents remained uncertain about the situation. This information reveals that the learners who 'strongly agreed' and 'agreed' with the statement are larger in number. A negligible number of the respondents stayed unsure about the situation. So, it can easily be deduced that the students at the undergraduate level consider social media helpful in improving their listening and speaking skills. 
Table 4-10 Audiovisual content on social media in English helps you to advance your comprehension skills, correct pronunciation, improve your accent, and gain fluency.

\begin{tabular}{|c|c|c|c|c|c|}
\hline & & Frequency & Percent & Valid Percent & Cumulative Percent \\
\hline \multirow{4}{*}{ Valid } & Strongly Agree & 40 & 48.2 & 48.8 & 48.8 \\
\hline & Agree & 39 & 47.0 & 47.6 & 96.3 \\
\hline & Neutral & 3 & 3.6 & 3.7 & 100.0 \\
\hline & Total & 82 & 98.8 & 100.0 & \\
\hline Missing & System & 1 & 1.2 & & \\
\hline Total & & 83 & 100.0 & & \\
\hline
\end{tabular}

Table 4-10 includes the results about audiovisual content on social media that may be helpful for the English language learners in advancing comprehension skills, correcting pronunciation, improving accent, and gaining fluency. The data shows that $40(48.8 \%)$ learners 'strongly agreed', 39 (47.6\%) learners 'agreed', and no learner 'disagreed' with the statement. However, only 3 learners stayed 'neutral'. It represents that the maximum number of the learners 'strongly agreed' and 'agreed' with the statement, but no one 'disagreed'. An insignificant number of the learners remained unsure about the situation. So, it can be construed that the audiovisual content on social media facilitates multiple skills of the English language learners.

Table 4-11 Writing in English on social media encourages you to use proper sentence structure with correct grammar while interacting with a larger audience.

\begin{tabular}{llcccc}
\hline & & Frequency & Percent & Valid Percent & Cumulative Percent \\
\hline \multirow{4}{*}{ Valid } & Strongly Agree & 38 & 45.8 & 46.3 & 46.3 \\
& Agree & 38 & 45.8 & 46.3 & 92.7 \\
& Neutral & 5 & 6.0 & 6.1 & 98.8 \\
& Disagree & 1 & 1.2 & 1.2 & 100.0 \\
\multirow{2}{*}{ Missing } & Total & System & 1 & 98.8 & 100.0 \\
Total & & 1.2 & & \\
\hline
\end{tabular}

The above Table 4-11 accompanies the data about the statement that social media persuades the students to use correct English grammar while communicating with a large audience. Out of 82 respondents, $38(46.3 \%)$ learners 'strongly agreed' and an equal number of the learners 'agreed' with the statement. Only one (1.2\%) learner disagreed with the statement while the rest of the learners remained undecided. It plainly shows that the learners who 'strongly agreed' and 'agreed' are much higher in number as compared to the learners who 'disagreed' or stayed 'neutral'. Therefore, it can easily be inferred from the above results that social media motivates the English language learners at the undergraduate level to use proper sentence structure with correct grammar while interacting with a large audience on social media. 
Table 4-12 Social media is useful in improving the writing skills of the English language learners at undergraduate level.

\begin{tabular}{llcccc}
\hline & & Frequency & Percent & Valid Percent & Cumulative Percent \\
\hline \multirow{4}{*}{ Valid } & Strongly Agree & 39 & 47.0 & 47.6 & 47.6 \\
& Agree & 37 & 44.6 & 45.1 & 92.7 \\
& Neutral & 6 & 7.2 & 7.3 & 100.0 \\
\multirow{2}{*}{ Missing } & Total & 82 & 98.8 & 100.0 & \\
Total & System & 1 & 1.2 & \\
\hline
\end{tabular}

The data in the above Table 4-12 contain the responses of the learners about improvement in writing skills of the English language learners by use of social media. The data indicates that 39 (47.6\%) learners 'strongly agreed' and 37 (45.1\%) learners 'agreed' with the statement, however, no one 'disagreed' with the statement. Only $6(7.3 \%)$ learners stayed uncertain about the statement. The results reveal that the learners who 'strongly agreed' and 'agreed' with the statement are much higher in number. Therefore, it can be easily interpreted from the results that social media plays a significant part in improving the writing skills of English language learners at the undergraduate level.

Table 4-13 Social media advances the language learnability of the English language learners at undergraduate level.

\begin{tabular}{llcccc}
\hline & & Frequency & Percent & Valid Percent & Cumulative Percent \\
\hline \multirow{4}{*}{ Valid } & Strongly Agree & 37 & 44.6 & 45.1 & 45.1 \\
& Agree & 38 & 45.8 & 46.3 & 91.5 \\
& Neutral & 7 & 8.4 & 8.5 & 100.0 \\
\multirow{2}{*}{ Missing } & Total & 82 & 98.8 & 100.0 & \\
Total & System & 1 & 1.2 & \\
\hline
\end{tabular}

The data presented in Table 4-13 is concerned with the role of social media in advancing the English learnability of the English language learners. There were $37(45.1 \%)$ learners who 'strongly agreed' and 38 (46.3\%) learners who 'agreed', while 7 (8.5\%) learners stayed undecided about the situation. This data clarify that a maximum number of the learners 'strongly agreed' and 'agreed' with the statement, and a very small number of the learners remained unsure about the situation. This explains that social media is influential in advancing the language learnability of English language learners at the undergraduate level.

Table 4-14 Presently, English is the most widely used language on social media; hence, social media can be considered a modern tool to learn the English language.

\begin{tabular}{llcccc}
\hline & & Frequency & Percent & Valid Percent & Cumulative Percent \\
\hline \multirow{3}{*}{ Valid } & Strongly Agree & 36 & 43.4 & 43.9 & 43.9 \\
& Agree & 37 & 44.6 & 45.1 & 89.0 \\
& Neutral & 8 & 9.6 & 9.8 & 98.8
\end{tabular}




\begin{tabular}{|c|c|c|c|c|c|}
\hline & Disagree & 1 & 1.2 & 1.2 & 100.0 \\
\hline & Total & 82 & 98.8 & 100.0 & \\
\hline Missing & System & 1 & 1.2 & & \\
\hline Total & & 83 & 100.0 & & \\
\hline
\end{tabular}

Table 4-14 presents data regarding the importance of social media as a modern tool to learn the English language. The data includes 36 (43.9\%) learners who 'strongly agreed' and 37 $(45.1 \%)$ learners who 'agreed' with the statement. Only one learner 'disagreed' while 8 $(9.8 \%)$ learners stayed unsure about the statement. The results show that there were a large number of learners who 'strongly agreed' and 'agreed' with the statement. The number of learners who remained 'neutral' was far less than the number of the learners who 'strongly agreed' and 'agreed'. Only one learner 'disagreed' with the statement. This indicates that social media as a modern tool of communication plays an important role in learning the English language at the undergraduate level.

Table 4-15 Undergraduate students misspell English words frequently for speedy communication on social media.

\begin{tabular}{llcccc}
\hline & & Frequency & Percent & Valid Percent & Cumulative Percent \\
\hline \multirow{4}{*}{ Valid } & Strongly Agree & 14 & 16.9 & 17.1 & 17.1 \\
& Agree & 43 & 51.8 & 52.4 & 69.5 \\
& Neutral & 14 & 16.9 & 17.1 & 86.6 \\
& Disagree & 11 & 13.3 & 13.4 & 100.0 \\
\multirow{2}{*}{ Missing } & Total & System & 1 & 98.8 & 100.0 \\
Total & & 1.2 & & \\
\hline
\end{tabular}

The data in the above Table 4-15 corresponds to the responses of the English language learners concerning the misspelling of the English words as a part of fast communication on social media. According to the data, 14 (17.1\%) learners 'strongly agreed' and $43(52.4 \%)$ learners 'agreed' with the statement. However, 11 (13.4\%) learners 'disagreed' while 14 $(17.1 \%)$ learners stayed 'neutral' about the statement. This reveals that most of the learners 'agreed' and least of the respondents 'disagreed' with the statement. The learners who 'strongly agreed' were more than the respondents who 'disagreed'. The learners who remained confused about the statement were more than the learners who 'strongly agreed'. Keeping in view the above results, it can easily be understood that the majority of English language learners misspell the English words during their quick communication on social media.

Table 4-16 Undergraduate students employ short sentences with no care of English grammar for quick communication on social media.

\begin{tabular}{lccccc}
\hline & & Frequency & Percent & Valid Percent & Cumulative Percent \\
\hline Valid & Strongly Agree & 14 & 16.9 & 17.1 & 17.1
\end{tabular}




\begin{tabular}{llcccc}
\hline & Agree & 40 & 48.2 & 48.8 & 65.9 \\
& Neutral & 15 & 18.1 & 18.3 & 84.1 \\
& Disagree & 13 & 15.7 & 15.9 & 100.0 \\
Missing & Total & 82 & 98.8 & 100.0 & \\
Total & System & 1 & 1.2 & \\
\hline
\end{tabular}

The results given in Table 4-16 illustrate the responses of the learners pertaining the misuse of English grammar by the English language learners on social media. The data indicates that there were 14 learners (17.1\%) who 'strongly agreed' and 40 learners (48.8\%) who 'agreed' with the statement. While there were $13(15.9 \%)$ learners who 'disagreed' with the statement but $15(18.3 \%)$ remained uncertain about the situation. The responses depict that the number of learners who 'agreed' were maxim in number while the learners who 'disagreed' with the statement were minimum in number. The learners who stayed 'neutral' and the learners who 'strongly agreed' were nearly equal in number. It shows that a sizable number of undergraduate students employ sentences on social media without focusing on English grammar.

Table 4-17 Written conversations on social media are ultimately deteriorating grammar of the English language learners at undergraduate level.

\begin{tabular}{llcccc}
\hline & & Frequency & Percent & Valid Percent & Cumulative Percent \\
\hline \multirow{4}{*}{ Valid } & Strongly Agree & 12 & 14.5 & 14.6 & 14.6 \\
& Agree & 34 & 41.0 & 41.5 & 56.1 \\
& Neutral & 10 & 12.0 & 12.2 & 68.3 \\
& Disagree & 26 & 31.3 & 31.7 & 100.0 \\
\multirow{2}{*}{ Missing } & Total & 82 & 98.8 & 100.0 & \\
Total & System & 1 & 1.2 & & \\
\hline
\end{tabular}

Table 4-17 comprises the data regarding the statement that written communications on social media are deteriorating the grammar of the English language learners. According to the results, $12(14.6 \%)$ respondents 'strongly agreed', $34(41.5 \%)$ respondents 'agreed', 26 $(31.7 \%)$ respondents 'disagreed', and $10(12.2 \%)$ respondents stayed 'neutral' about the statement. It shows that the learners who 'agreed' with the statement were the highest in number. The learners who 'disagreed' with the statement were less than those who 'agreed' but more than those who 'strongly agreed' and stayed 'neutral' about the statement. This reveals that the majority of the learners consider written conversations on social media ultimately deteriorating the grammar of the English language learners, however, a substantial number of the learners also 'disagreed' with the statement.

Table 4-18 Undergraduate students frequently employ shortened forms (abbreviations and acronyms) in their written conversations on social media.

\begin{tabular}{lccccc}
\hline & & Frequency & Percent & Valid Percent & Cumulative Percent \\
\hline Valid & Strongly Agree & 16 & 19.3 & 19.5 & 19.5
\end{tabular}




\begin{tabular}{llcccc}
\hline & Agree & 55 & 66.3 & 67.1 & 86.6 \\
& Neutral & 7 & 8.4 & 8.5 & 95.1 \\
& Disagree & 4 & 4.8 & 4.9 & 100.0 \\
& Total & 82 & 98.8 & 100.0 & \\
Missing & System & 1 & 1.2 & \\
Total & & 83 & 100.0 & \\
\hline
\end{tabular}

Table 4-18 accompanies the outcomes about the frequent use of shortened forms of English words and phrases on social media by the English language learners. Out of 82 learners, 16 (19.5\%) learners 'strongly agreed', and 55 (67.1\%) learners 'agreed' that the English language learners employ shortened forms during their communications on social media. There were only 4 (4.9\%) learners who 'disagreed' with the statement while the rest of the respondents remained unsure about the situation. The results signify that the learners who agreed with the statement were maximum in number and the learners who 'strongly agreed' were also more than the learners who 'disagreed' or remained unsure about the situation. This strikingly figures out that most of the English language learners at the undergraduate level frequently employ shortened forms in their written conversations on social media.

Table 4-19 Undergraduate Students routinely employ slang in their written conversations on social media.

\begin{tabular}{|c|c|c|c|c|c|}
\hline & & Frequency & Percent & Valid Percent & Cumulative Percent \\
\hline \multirow{5}{*}{ Valid } & Strongly Agree & 16 & 19.3 & 19.5 & 19.5 \\
\hline & Agree & 54 & 65.1 & 65.9 & 85.4 \\
\hline & Neutral & 8 & 9.6 & 9.8 & 95.1 \\
\hline & Disagree & 4 & 4.8 & 4.9 & 100.0 \\
\hline & Total & 82 & 98.8 & 100.0 & \\
\hline Missing & System & 1 & 1.2 & & \\
\hline Total & & 83 & 100.0 & & \\
\hline
\end{tabular}

The results for the statement "Undergraduate students routinely employ slang in their written conversations on social media" are given in above Table 4-19. According to the results 16 (19.5\%) respondents 'strongly agreed' and 54 (65.9\%) learners 'agreed' with the statement. However, 8 (9.8\%) learners remained undecided while 4 (4.9\%) learners 'disagreed' with the statement. The results point out that the maximum learners 'agreed' with the statement and the learners who 'strongly agreed' were more than the learners who 'disagreed' or stayed 'neutral' about the statement. So, it can be easily interpreted from the results that undergraduate students are used to employing slang in their written communications on social media.

Table 4-20 Undergraduate students consciously or subconsciously incorporate shortened forms, slang, and misspelled words in their academic writings.

\begin{tabular}{llcccc}
\hline & & Frequency & Percent & Valid Percent & Cumulative Percent \\
\hline \multirow{2}{*}{ Valid } & Strongly Agree & 8 & 9.6 & 9.8 & 9.8 \\
& Agree & 22 & 26.5 & 26.8 & 36.6
\end{tabular}




\begin{tabular}{llcccc}
\hline & Neutral & 15 & 18.1 & 18.3 & 54.9 \\
& Disagree & 28 & 33.7 & 34.1 & 89.0 \\
& Strongly Disagree & 9 & 10.8 & 11.0 & 100.0 \\
& Total & 82 & 98.8 & 100.0 & \\
Missing & System & 1 & 1.2 & \\
Total & & 83 & 100.0 & \\
\hline
\end{tabular}

Table 4-20 contains the results about conscious or subconscious use of shortened forms, slangs, and misspelled words by the undergraduate students in their academic writings. Out of 82 learners, $8(9.8 \%)$ learners 'strongly agreed' and $22(26.8 \%)$ learners 'agreed' that the students employ shortened forms, slang, and misspelled words in their academic writings. While 9 (11\%) learners 'strongly disagreed' and 28 (34.1\%) learners 'disagreed' with the statement. However, 15 (18.3\%) learners remained uncertain about the statement and stayed neutral. The results explicitly expose that the learners who 'disagreed' with the statement were the highest in number while a significant number of the learners also 'agreed' with the statement. The learners who 'strongly agreed' were slightly more than those who 'strongly disagreed' with the statement. A considerable number of the learners also stayed in the middle of the road. Hence, it is construed that most of the learners do not incorporate shortened forms, slangs, and misspelled words in their academic writings.

Table 4-21Shortened forms (of words or phrases) and slang may be employed in academic writings.

\begin{tabular}{llcccc}
\hline & & Frequency & Percent & Valid Percent & Cumulative Percent \\
\hline \multirow{6}{*}{ Valid } & Strongly Agree & 5 & 6.0 & 6.1 & 6.1 \\
& Agree & 6 & 7.2 & 7.3 & 13.4 \\
& Neutral & 9 & 10.8 & 11.0 & 24.4 \\
& Disagree & 30 & 36.1 & 36.6 & 61.0 \\
& Strongly Disagree & 32 & 38.6 & 39.0 & 100.0 \\
\multirow{2}{*}{ Missing } & Total & 82 & 98.8 & 100.0 & \\
Total & System & 1 & 1.2 & & \\
\hline
\end{tabular}

The data in Table 4-21 covers the opinions of the learners about the statement that shortened forms or slangs may be employed in academic writings by undergraduate students. Out of 82 learners, there were 32 (39\%) learners who 'strongly disagreed' and $30(36.6 \%)$ learners who 'disagreed' with the statement. However, 6 (7.3\%) respondents 'agreed' while 5 (6.1\%) learners 'strongly agreed' with the statement. The rest of the learners remained 'neutral' about the statement. It can be interpreted from the results that the learners who 'strongly agreed' with the statement are the highest in number while the learners who 'strongly agreed' are the lowest in number. The learners who 'disagreed' are far more in number than those who 'agreed' and those who remained 'neutral'. It markedly indicates that the students at the undergraduate level do not favor the use of shortened forms or slang in their academic writings. 
Table 4-22 Regular and excessive use of shortened forms and slang in social media communications adversely affects the academic writings of the English language learners.

\begin{tabular}{|c|c|c|c|c|c|}
\hline & & Frequency & $\begin{array}{l}\text { Percent } \\
\end{array}$ & Valid Percent & Cumulative Percent \\
\hline \multirow{5}{*}{ Valid } & Strongly Agree & 9 & 10.8 & 11.0 & 11.0 \\
\hline & Agree & 30 & 36.1 & 36.6 & 47.6 \\
\hline & Neutral & 17 & 20.5 & 20.7 & 68.3 \\
\hline & Disagree & 26 & 31.3 & 31.7 & 100.0 \\
\hline & Total & 82 & 98.8 & 100.0 & \\
\hline Missing & System & 1 & 1.2 & & \\
\hline Total & & 83 & 100.0 & & \\
\hline
\end{tabular}

The data given in Table 4-22 gathers the opinions of the learners concerning the adverse effects of excessive use of shortened forms and slang in social media communications on academic writings of the English language learners at the undergraduate level. Among 82 respondents, $30(36.6 \%)$ learners 'agreed' and 9 (11\%) learners 'strongly agreed' that excessive use of shortened forms and slang in social media communications adversely affects academic writings of the English language learners. Though, there were $26(31.7 \%)$ learners who 'disagreed' with the statement while 17 (20.7\%) remained unsure about the statement. These results highlight that most of the learners 'agreed' with the statement while a considerable number of the learners also 'disagreed' with the statement. The learners who 'strongly agreed' also reinforced the opinion of the learners who 'agreed'. A number of the learners also seemed confused about the statement and stayed neutral. Hence, the results suggest that most English language learners believe that the rich and unnecessary use of shortened forms and slang in social media communications negatively impacts the academic writings of the English language learners at the undergraduate level.

Table 4-23 Use of informal and improper English language on social media is a future risk to Standard English.

\begin{tabular}{llcccc}
\hline & & Frequency & Percent & Valid Percent & Cumulative Percent \\
\hline \multirow{4}{*}{ Valid } & Strongly Agree & 33 & 39.8 & 40.2 & 40.2 \\
& Agree & 39 & 47.0 & 47.6 & 87.8 \\
& Neutral & 4 & 4.8 & 4.9 & 92.7 \\
& Disagree & 6 & 7.2 & 7.3 & 100.0 \\
\multirow{2}{*}{ Missing } & Total & 82 & 98.8 & 100.0 & \\
Total & System & 1 & 1.2 & & \\
\hline
\end{tabular}

The above Table 4-23 accompanies the results for the statement that informal and improper use of the English language on social is a future risk to Standard English. Amongst 82 learners, $33(40.2 \%)$ learners 'strongly agreed' and 39 (47.6) learners 'agreed' with the statement. However, 6 (7.3\%) learners disagreed with the statement while $4(4.9 \%)$ learners remained 'neutral'. The outcomes show that most of the learners 'agreed' and a sizeable number of the learners 'strongly agreed' with the statement. The learners who 'disagreed' 
with the statement were small in number and the learners who stayed 'neutral' were negligible. This indicates that the majority of the learners view the informal and improper use of English on social media a future risk to Standard English.

\section{Inferential Analysis}

The purpose of the inferential analysis is to conclude the sample when examining each member of the entire population is almost impossible (Bryman \& Cramer, 2002). In the present work, the inferential analysis includes one-sample T-test, correlations, and linear regression.

\section{One-Sample T-test}

A one-sample T-test is generally used to determine the statistical difference between means by comparing the means in the sample of a population to a pre-specified or hypothesized value of the mean. It signifies whether the sample comes from a specific mean. The purpose of running a one-sample T-test is to determine whether the null hypotheses are rejected or not (Bryman \& Cramer, 2002).

Table 4-24 One-Sample Statistics

\begin{tabular}{ccccc}
\hline & N & Mean & Std. Deviation & Std. Error Mean \\
\hline Social Media Impact & 82 & 2.0457 & .54925 & .06065 \\
\hline
\end{tabular}

Table 4-24 illustrates that the mean for social media impact $(2.0 \pm 0.55)$ is lower than the prespecified value for mean which was 3 .

Table 4-25 One-Sample Test

\begin{tabular}{lcccccc}
\hline & & & \multicolumn{3}{c}{ Test Value $=3$} & \\
& T & Df & Sig. (2-tailed) & Mean Difference & 95\% Confidence Interval of the \\
Difference & Lower & Upper \\
\hline Social Media Impact & -15.733 & 81 & .000 & -.95427 & -1.0750 & -.8336 \\
\hline
\end{tabular}

The results for the one-sample T-test are given in Table 4-25. The top row provides the value for the pre-specified mean which was 3 . In the table, $\mathrm{T}$ is -15.7 which indicates obtained value of the t-statistic. Df is the degree of freedom which is $\mathrm{N}-1=81$ and ' $p$ ' is the probability of obtaining the observed t-value when the null hypothesis is correct. The sample means are significantly different as $\mathrm{p}(0.000)$ is less than alpha (.05) and t-value is also very small. The mean difference (-.95) is given with lower and upper limits at $95 \%$ confidence interval (Samuels \& Gilchrist, 2014). Hence, the results indicate that social media impact either positive or negative is statistically significant leading to the rejection of null hypotheses of the study. 


\section{Correlations}

Table 4-26 Correlations

\begin{tabular}{llcc}
\hline & & $\begin{array}{c}\text { Social Media } \\
\text { Language }\end{array}$ & $\begin{array}{c}\text { Social Media } \\
\text { Learning }\end{array}$ \\
\hline \multirow{2}{*}{ Social Media Language } & Pearson Correlation & 1 & $.518^{* *}$ \\
& Sig. (2-tailed) & & .000 \\
& $\mathrm{~N}$ & 82 & 82 \\
Social Media Learning & Pearson Correlation & $.518^{* *}$ & 1 \\
& Sig. (2-tailed) & .000 & 82 \\
\hline
\end{tabular}

**. Correlation is significant at the 0.01 level (2-tailed).

Table 4-26 states the relationship between social media language and social media learning. The positive values ( 1 and .518 ) of correlation between social media language and social media learning were observed with $.000 \mathrm{sig}$. value. In the table, the same values have been observed diagonally for both variables. The positive values of correlation for both the variables indicate that both the variables are perfectly positively interlinked. Since, ' $p$ ' value $(\mathrm{p}=.000)$ is less than alpha (.05) therefore the correlation is statistically significant (Chandra Kafle, 2019). Hence, the correlation between the variables rejects the null hypotheses of the research.

\section{Linear Regression Analysis}

Linear regression is used to predict the values of variables in which the value of one variable (dependent variable/ outcome variable) depends on the value of another variable (independent variable/ predictor variable) (Chandra Kafle, 2019).

Table 4-27ANOVA ${ }^{\mathrm{a}}$

\begin{tabular}{llccccc}
\hline Model & & Sum of Squares & Df & Mean Square & F & Sig. \\
\hline \multirow{3}{*}{1} & Regression & 11.556 & 1 & 11.556 & 29.267 & $.000^{\mathrm{b}}$ \\
& Residual & 31.587 & 80 & .395 & & \\
& Total & 43.143 & 81 & & & \\
\hline
\end{tabular}

a. Dependent Variable: Social Media Learning

b. Predictors: (Constant), Social Media Language

ANOVA lets us know how significant our model is. The sig. value $(\mathrm{p}=.000)$ in Table $4-27$ is less than alpha (.05) which indicates that the model is highly significant statistically. The model significance can be reported as $\mathrm{F}(1,80)=29.267, \mathrm{p}=.000$ (Samuels \& Gilchrist, 2014b). Thus, it can easily be interpreted that the outcome variable (social media learning) has significantly been impacted by the predictor (social media language). 
Table 4-28Coefficients ${ }^{\mathrm{a}}$

\begin{tabular}{llcccccc}
\hline Model & & Unstandardized Coefficients & $\begin{array}{c}\text { Standardized } \\
\text { Coefficients } \\
\text { Beta }\end{array}$ & T & Sig. \\
\hline \multirow{2}{*}{1} & B & Std. Error & .483 & .206 & & 7.214 & .000 \\
& (Constant) & .649 & .120 & .518 & 5.410 & .000 \\
\hline
\end{tabular}

a. Dependent Variable: Social Media Learning

The Table 4-28 regards both the variables distinctively using a linear regression equation that whether the variables are significant or not. In this table, the sig. value of predictor 'constant' is not important to consider. However, the sig. value for both the variables $(p=.000)$ is less than alpha (.05), and therefore, the results for the coefficients of variables show a high significance statistically (Kpolovie, 2017). So, it can be construed that the English language used in social media highly impacts the language learning of the English language learners. Hence, the analysis rejects the null hypotheses of the study and accepts alternate hypotheses.

\section{Findings}

The results on subsequent completion of the descriptive analysis revealed that social media played a dominant role in improving the English language of the learners. Social media assisted the learners to learn new English words and phrases enhancing their vocabulary. The results of the study indicated that listening and watching audiovisual content on social media in the English language proved instrumental in enhancing the listening and speaking skills of the learners. It has also been unfolded that the online written conversations on social media psychologically urge the learners to write English in a better way using correct grammar and appropriate vocabulary which help in improving the writing skills of the learners. Expeditiously written conversations on social media also help in improving the readability and comprehension skills of the learners as well. The results conspicuously indicated that social media advances the English learnability of the English language learners and is instrumental in enhancing vocabulary and improving the overall reading, writing, listening and speaking skills of the learners. However, it was also found that the excessive use of shortened forms of words and phrases, slang and short sentences with incorrect grammar on social media adversely affect the academic writings of the learners.

Overall, it was revealed that the majority of the learners tend to favour learning English through social media which showed a positive impact of social media language on the English language learners. Similarly, the results of inferential analysis indicated that the dependent variable (social media learning) has significantly been impacted by the independent variable (social media language). It corroborates that the analysis rejects the null hypotheses and accepts alternate hypotheses. Finally, the findings of both descriptive and inferential analyses substantiated that the English language used in social media positively impacted the perception and language learnability of the English language learners. Hence, it can easily be construed from the whole analysis that the social media strengths were by far greater than the social media weaknesses. 


\section{Conclusion and Suggestion}

The overall perception of the learners in this study has supported the strengths of the English language used in social media. However, it has also been insinuated through learners' perception that the overwhelming use of shortened forms such as abbreviations and acronyms, slang, misspellings, and incorrect grammar inimically affect the academic writing of the learners. Hence, the superfluous use of shortened forms in academic writings must be avoided by the learners. In the present era of technology, the abundant and informal use of the English language is becoming a big hurdle in writing Standard English on social media. So, there exists a huge potential that social media users may take Standard English for granted in the future. Nonetheless, despite pros and cons, the overall perception of the English language learners validates that the English language used in social media positively impacts the learnability of the English language learners. Hence, it can undoubtedly be summed up that the strengths of the English language used in social media are remarkably greater than those of the weaknesses. Similar researches may be suggested to be carried out at profound levels to know the impact of the English language used in social media on English language learners considering each language skill separately i.e., reading, writing, listening, and speaking. Furthermore, in-depth studies may be carried out in diverse contexts on the usage of slang in social media as well as the language of social media commenting.

\section{Conflict of Interest}

The author declares no conflict of interest

\section{Funding}

The study was not funded by any institution/ university.

\section{Availability of Data and Material}

The data that support the findings of this study are available from the corresponding author, upon reasonable request.

\section{References}

Abbasova, M. (2016a). The Impact Of Social Networks On Students'english Language In Azerbaijan. Education, 24, 23.08.

Abraham, J., \& Saini, C. (2015). Using Social Media for Educational Purposes: Approaches and Challenges.

Al-Rahmi, W., \& Othman, M. (2013). The impact of social media use on academic performance among university students: A pilot study. Journal of information systems research and innovation, 4(12), 1-10.

Alfaki, I. M. (2018). Towards a digital world: Using social networks to promote learner's language. 
Ansari, J. A. N., \& Khan, N. A. (2020). Exploring the role of social media in collaborative learning the new domain of learning. Smart Learning Environments, 7(1), 1-16.

Bakeer, A. M. (2018). Effects of Information and Communication Technology and Social Media in Developing Students' Writing Skill: A Case of Al-Quds Open University. International Journal of Humanities and Social Science, 8(5), 45-53.

Belal, A. (2014). Influence of digital social media in writing and speaking of tertiary level student. BRAC University.

Brown, E. (2015). Learning/teaching English as a second language in the information age: A study on the influences of new media on Swedish students in the English classroom.

Bryman, A., \& Cramer, D. (2002). Quantitative Data Analysis with SPSS for Windows. A Guide for Social Scientists.

Bureau, P. R. (2012). World population data sheet 2012: PRB Washington (DC).

Chandra Kafle, S. (2019). Correlation and Regression Analysis Using SPSS.

Coyle, C., \& Vaughn, H. (2008). Social networking: Communication revolution or evolution? Bell Labs Technical Journal, 13, 13-17. doi: 10.1002/bltj.20298

Davis III, C. H., Deil-Amen, R., Rios-Aguilar, C., \& Gonzalez Canche, M. S. (2012). Social Media in Higher Education: A literature review and research directions.

Delport, C. (2005). Quantitative data collection methods. Research at grass roots for the social sciences and human service professions, 3, 159-191.

Derakhshan, A., \& Hasanabbasi, S. (2015). Social Networks for Language Learning. Theory and Practice in Language Studies, 5, 1090. doi: 10.17507/tpls.0505.25

Dickey, I. J., \& Lewis, W. F. (2010). The evolution (revolution) of social media and social networking as a necessary topic in the marketing curriculum: a case for integrating social media into marketing classes. Advances in Marketing: Embracing Challenges and Change-A Global Perspective.

Edwin, K. (2019). Reliability and Validity of Research Instruments Correspondence to kubaiedwin@yahoo.com.

Faizi, R., \& El Fkihi, S. (2018). Investigating the Role of Social Networks in Enhancing Students' Learning Experience: Facebook as a Case Study. International Association for Development of the Information Society.

George, M. S. (2018). Developing Listening and Reading Skills through Social Media using Apps. Literary Studies, 3, 93-101.

Gibreel, M. (2018). The Impacts of Employing Native Speakers for Teaching English as a Second Language.

Greasley, P. (2007). Quantitative data analysis using SPSS: an introduction for health \& social science: McGraw-Hill Education (UK).

Haque, M. I. (2017). English Used in Social Media and Its Effect on the HSC Level Learners.

Hashmi, M. (2019). Impact of Mass Media in the Use of English Slang Words/Short Forms among Pakistani Students. INTERNATIONAL JOURNAL OF EDUCATIONAL SCIENCES, 24. doi: 10.31901/24566322.2019/24.1-3.1073

Hwang, C. C. (2005). Effective EFL education through popular authentic materials. Asian EFL Journal, 7(1), 90-101. 
Izmaylova, G., Zamaletdinova, G., \& Zholshayeva, M. (2017). Linguistic and Social Features of Slang.

J, A., Jaffar, A., Nurunnabi, M., \& Bano, S. (2021). The Impact of Social Media on Learning Behavior for Sustainable Education: Evidence of Students from Selected Universities in Pakistan. Sustainability, 11, 1683. doi: 10.3390/su11061683

Kauser, S., \& Awan, A. G. (2019). Impact of using social media on academic performance of students at graduate level: Evidence from Pakistan. Global Journal of Management, Social Sciences and Humanities, 5(1), 116-142.

Kpolovie, P. (2017). STATISTICAL ANALYSIS WITH SPSS FOR RESEARCH.

Kumi-Yebaoh, A., \& Blankson, H. (2014). Social media and use of technology in higher education. 217-234. doi: 10.4018/978-1-4666-6046-5.ch017

Latip-Yusoph, S. (2016). Language Trends in Social Media: Manifestations of Meranaws' Use of English on Facebook. US-China Foreign Lang, 14(7), 480-490.

Le, T. V. (2018). Social media in learning English in Vietnam.

Maclean, F., Jones, D., Carin-Levy, G., \& Hunter, H. (2013). Understanding Twitter. British Journal of Occupational Therapy, 76, 295. doi: $10.4276 / 030802213 X 13706169933021$

Mukhtar, S., Tatlah, I. A., \& Saeed, M. (2011). An analytical study of higher education system of Pakistan.

Namaziandost, E., \& Nasri, M. (2019). The Impact of Social Media on EFL Learners' Speaking Skill: A Survey Study Involving EFL Teachers and Students.

Namvar, F. (2014). The Use Of Slang Amongst Undergraduate Students Of A Malaysian Public University. JOURNAL OF ADVANCES IN LINGUISTICS, 3, 127-135. doi: 10.24297/jal.v3i1.2067

Ochonogor W. C., A. N. O., Achugbue I. E. (2012). The Impact of Text Message Slang (Tms) or Chartroom Slang on Students Academic Performance. International Journal of Internet of Things, 4. doi: 10.5923/j.ijit.20120102.01

Okumura, S. (2016). The use of an educational social networking site for English language learning beyond the classroom in a Japanese university setting.

Oliver, R. (2002). The role of ICT in higher education for the 21 st century: ICT as a change agent for education.

Owusu-Acheaw, M., \& Larson, A. G. (2015). Use of social media and its impact on academic performance of tertiary institution students: A study of students of Koforidua Polytechnic, Ghana. Journal of Education and Practice, 6(6), 94-101.

Rao, P. (2019a). THE IMPACT OF SOCIAL MEDIA ON LEARNING ENGLISH: A CRITICAL STUDY IN ENGLISH LANGUAGE TEACHING (ELT) CONTEXT. 4, 266-274.

Rao, P. (2019b). THE ROLE OF ENGLISH AS A GLOBAL LANGUAGE. 4, 65-79.

Raut, V., \& Patil, P. (2016). Use of Social Media in Education: Positive and Negative impact on the students. International Journal on Recent and Innovation Trends in Computing and Communication, 4(1), 281-285.

Raza, M. (2015). Language Attitude and English Language Learning in Pakistan. COMMUNICATION STUDIES AND LANGUAGE PEDAGOGY, 1, 95-110. 
Roopa, S., \& Menta Satya, R. (2012). Questionnaire Designing for a Survey. The Journal of Indian Orthodontic Society, 46, 37-41. doi: 10.5005/jp-journals-10021-1104

Rudis, D., \& Postic, S. (2018). Influence of Video Games on The Acquisition of the English Language. Verbum, 8, 112. doi: 10.15388/Verb.2017.8.11354

Samuels, P., \& Gilchrist, M. (2014). Independent Samples t-test.

Siddiqui, S., \& Singh, T. (2016). Social media its impact with positive and negative aspects. International Journal of Computer Applications Technology and Research, 5(2), 7175.

Singh, S., \& Sachan, M. (2017). Importance and Challenges of Social Media Text. International Journal of Advanced Computer Research, 8, 831-834. doi: 10.26483/ijarcs.v8i3.3108

Starkey, L. (2011). Evaluating learning in the 21st century: A digital age learning matrix. Technology, Pedagogy and Education, 20, 19-39. doi: 10.1080/1475939X.2011.554021

Suša Vugec, D. (2014). Digital Immigrants and Digital Natives: Learning Business Informatics at Higher Educational Level. Business Systems Research Journal, 5. doi: 10.2478/bsrj-2014-0012

Tariq, W., Mehboob, M., Khan, M., \& Ullah, F. (2012a). The Impact of Social Media and Social Networks on Education and Students of Pakistan. IJCSI International Journal of Computer Science Issues, 9.

Thurairaj, S., Hoon, E. P., Roy, S. S., \& Fong, P. W. (2015). Reflections of Students' Language Usage in Social Networking Sites: Making or Marring Academic English. Electronic Journal of e-Learning, 13(4), 302-316.

Van Den Beemt, A., Thurlings, M., \& Willems, M. (2020). Towards an understanding of social media use in the classroom: a literature review. Technology, Pedagogy and Education, 29(1), 35-55.

Walker, A., \& Zur, O. (2011). On digital immigrants and digital natives: How the digital divide affects families, educational institutions, and the workplace. Zur InstituteOnline Publication.

Wil, C. S. C., Yunus, M. M., \& Suliman, A. (2019). The use of social media to assist writing skills among secondary pupils. International Journal of Academic Research in Progressive Education and Development, 8(3), 224-236.

Willems, J., Adachi, C., Bussey, F., Doherty, I., \& Huijser, H. (2018). Debating the use of social media in higher education in Australasia: Where are we now? Australasian Journal of Educational Technology, 34(5).

Wilson, F. (2018). The Effect of Social Media on the Spelling Ability of Students: A Case Study of Federal College of Education (FCE) Yola. Edelweiss Applied Science and Technology, 262-274. doi: 10.33805/2576-8484.153

Winarto, E. (2019). Modelling Abbreviation In Internet Slang: a Comparison Study of Indonesian Internet Slang and English Internet Slang. ETERNAL (English Teaching Journal), 10. doi: 10.26877/eternal.v10i2.4973 
Xodabande, I. (2017). The effectiveness of social media network telegram in teaching English language pronunciation to Iranian EFL learners. Cogent education, 4(1), 1347081. 